Journal of Engineering and Applied Sciences 14 (14): 4742-4746, 2019

ISSN: 1816-949X

(C) Medwell Journals, 2019

\title{
Fatigue Strength of Nanocomposite Under High Temperature
}

\author{
Hussain J.M. Al-Alkawi, Maha N. Abdulridah and Raad H. Majid \\ University of Technology, Baghdad, Iraq
}

\begin{abstract}
The influence of reinforced ratio 6 wt.\% of alumina particles of $\mathrm{Al}_{2} \mathrm{O}_{3}$ size with aluminum alloy 7100 metal matrix on constant fatigue strength and life at $200^{\circ} \mathrm{C}$ was studied. The experimental results revealed that the fatigue strength improvement factor FSIF for the composite was obtained to be from 0.84-4.84. The FSIF for the nanocomposite tested at $200^{\circ} \mathrm{C}$ exhibited for $10^{3}$ and $10^{5}$ cycles, respectively, at Room Temperature (RT) and the net FSIF was recorded as 4 , the value of 7.29-7.4\% at $10^{3}$ and $10^{5}$ cycles, respectively with 0.11 net FSIF. The addition of nanoreinforced material resulted to rais the fatigue endurance limit at $10^{7}$ cycles from 47-51.8 $\mathrm{MPa}$ and from $46-50.86 \mathrm{MPa}$ at $\mathrm{RT}$ and $200^{\circ} \mathrm{C}$, respectively.
\end{abstract}

Key words: Aluminum alloy 7100 , alumina, stir casting, high temperature fatigue behavior, matrix, fatigue endurance

\section{INTRODUCTION}

Aluminum alloys have high corrosion resistance, high thermal conductivity, sufficient strength characteristics, recyclability, ductility, durability and especially, low density. Therefore, it can be widely used in many areas of industry such as aerospace, architectural construction, marine industries and particularly in the automotive applications. Now a days, especially in the automotive industry, demands are increasing day by day and aluminum does not satisfy some case. So that, production industry has begun to look for alternative engineering materials. One of the engineering materials is composite. Composite materials consist of two or more materials. One of these materials is called reinforcement and other one is called matrix. Fibers, particulates or whiskers are examples of reinforcements and metals, plastics or ceramics are examples of matrix material. In metal matrix composites systems, aluminum and its alloys have been drawn attention, especially for last 20 years. Silicon Carbide $(\mathrm{SiC})$ and Aluminum Oxide $\left(\mathrm{Al}_{2} \mathrm{O}_{3}\right)$ are the most commonly used reinforcements (Aybarc et al., 2018). So that, this study deals with aluminum metal matrix composites in which $\mathrm{Al}_{2} \mathrm{O}_{3}$ were used as reinforcements materials with average size $(20-30 \mathrm{~nm})$ tested under fatigue and thermal fatigue to understand the effect of nanomaterial on the improvement of the thermal fatigue properties. Fatigue of metals reduced under elevated temperature. The 2024-T4 aluminum alloy was subjected to $150^{\circ} \mathrm{C}$ under constant fatigue tests and compared to the Room Temperature (RT). The experimental results revealed that a decrease in fatigue life of about $80 \%$ and significantly reduction was observed in fatigue strength (Majeed et al., 2010).
Stocker et al. (2009) studied the fatigue of super alloy $\mathrm{RR} 1000$ at $650^{\circ} \mathrm{C}$. They concluded that a major reduction in fatigue strength and life was observed when compared to the fatigue at dry condition (RT). Mege-Revil et al. (2010) studied TiSin and TiSin AIN nanocomposites coatings and thermomechanical properties and compared these properties with the thermal fatigue. The fatigue resistance was studied in isothermal, dynamic as well as cycling ( 10 cycles rms $25-800-25^{\circ} \mathrm{C}$ ) conditions. Thermal cycling observed high resistance of nanocomposites while the metal without nano showed reduction in fatigue resistance.

Zhang et al. (2006) studied the performance of thermal fatigue and creep resistance of nanocomposite solder in microelectronic/optoelectronic packaging. A comparison between the performance of thermal fatigue and the traditional solder was made. The results revealed that the nano-composite solder was much better fatigue resistance and creep resistance due to the uniformly distributed nanosized through the grain boundary and provided effective impediment to dislocation movement. In the current work, the constant fatigue behavior of 7100 Al. alloy $/ 6$ wt. $\% \mathrm{Al}_{2} \mathrm{O}_{3}$ nanocomposite reinforced by $6 \mathrm{wt} . \%$ alumina was investigated. A comparison between the fatigue strength and life for the above composite with the base metal (matrix) was made.

\section{MATERIALS AND METHODS}

\section{Experimental investigation}

Material selection: The matrix used in the present research is the aluminum alloy 7100 in the composite material which is used in different applications. Table 1 states chemical composition of 7100 aluminum alloy. While the mechanical properties are presented in Table 2.

Corresponding Author: Hussain J.M. Al-Alkawi, University of Technology, Baghdad, Iraq 




Fig. 1: Rotating bending fatigue specimen (cantilever beam) according to the American Society for testing and materials (AST81-8)

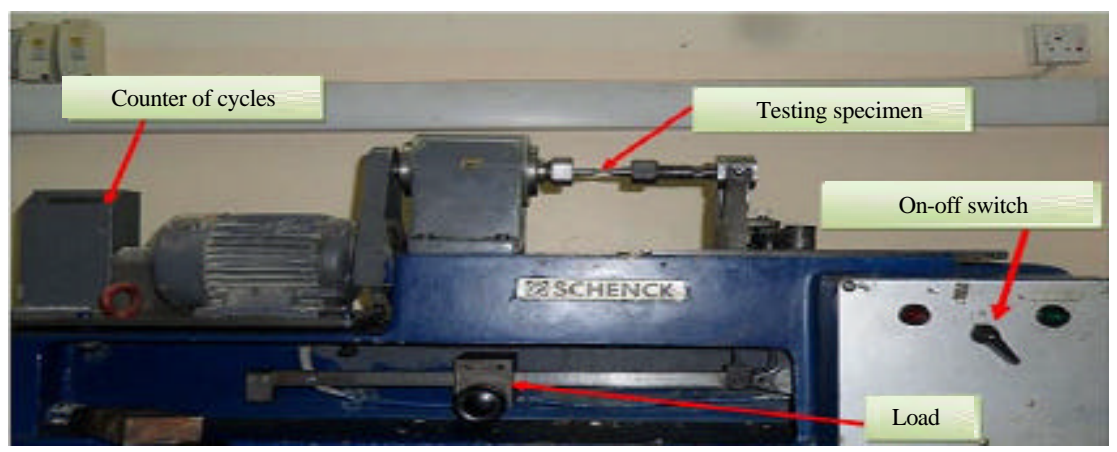

Fig. 2: Rotating bending testing machine

Fabrication of $7100 \mathrm{Al}$. alloy $\mathrm{Al}_{2} \mathrm{O}_{3}$ composite stir casting route: The method used to manufacture the nanocomposite is the stir casting method. This method includes several steps as follows:

- $\quad 7100 \mathrm{Al}$. alloy is cutting into cubes $(1-2) \mathrm{cm}^{3}$ then washed with alcohol and followed by water several times

- Dry the parts that were washed with steam of hot air at a temperature $100^{\circ} \mathrm{C}$

- Then this parts heated by an electric heater at $200^{\circ} \mathrm{C}$

- Lift the oven covers and carry the resulting parts of the heating process then close the oven cover tightly. Then, withdrawn air from the oven using vacuum

- The oven pumped with the argon gas then heated into $800^{\circ} \mathrm{C}$

- The Alumina $\left(\mathrm{Al}_{2} \mathrm{O}_{3}\right)$ are heated to $200^{\circ} \mathrm{C}$

- The nanoparticles are added to the molten 7100 Al.alloy through the gas pump

- First, the temperature of furnace is raised over the liquid temperature of $\mathrm{Al}$ about $850^{\circ} \mathrm{C}$ after that cool it less from $650^{\circ} \mathrm{C}$

- Four minutes are designed for stirring and with stirring speed $450 \mathrm{rpm}$

- The mixing are heated to $850 \pm 10^{\circ} \mathrm{C}$

- At last, the liquid is poured into molds to obtain an aluminum rod
Table 1: Chemical composition of $7100 \mathrm{Al}$. alloy

\begin{tabular}{llcc}
\hline $\begin{array}{l}\text { Chemical } \\
\text { compositions }\end{array}$ & $\begin{array}{c}\text { Element wt.\% } \\
\text { of Al 7100 }\end{array}$ & $\begin{array}{c}\text { Chemical } \\
\text { composition }\end{array}$ & $\begin{array}{c}\text { Element wt.\% } \\
\text { of Al 7100 }\end{array}$ \\
\hline $\mathrm{Zn}$ & 2.0 & $\mathrm{Cr}$ & 0.0402 \\
$\mathrm{Mg}$ & 1.5. & $\mathrm{~Pb}$ & 0.1550 \\
$\mathrm{Si}$ & 0.764 & $\mathrm{Sn}$ & 0.1140 \\
$\mathrm{Cu}$ & 0.441 & $\mathrm{Ca}$ & 0.0200 \\
$\mathrm{Fe}$ & 1.0 & $\mathrm{~V}$ & 0.0121 \\
$\mathrm{Ti}$ & 0.0404 & Others & 0.1350 \\
$\mathrm{Mn}$ & 0.391 & Rem. Al & 93.4194 \\
\hline
\end{tabular}

Table 2: Mechanical properties of $7100 \mathrm{Al}$. alloy

\begin{tabular}{|c|c|c|}
\hline Variables & \multicolumn{2}{|c|}{ 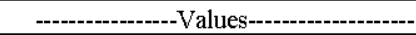 } \\
\hline Wt.\% & 0 & 6 \\
\hline$\sigma \mathrm{u}(\mathrm{MPa})$ & 115 & 165 \\
\hline oy (MPa) & 82 & 126 \\
\hline $\mathrm{E}(\mathrm{GPa})$ & 67 & 72.3 \\
\hline $\mathrm{G}(\mathrm{GPa})$ & 26.2 & 27.59 \\
\hline$\mu$ & 0.28 & 0.31 \\
\hline $\mathrm{HV}\left(\mathrm{kgf} / \mathrm{mm}^{2}\right)$ & 74 & 90 \\
\hline$e(\%)$ & 16.72 & 14.2 \\
\hline
\end{tabular}

Fatigue test: The specimens of the fatigue test were prepared according to the machines manual as shown in Fig. 1. The specimens were manufactured and tested to generate the S-N curve by an alternating bending specification of fatigue test machine (rotating bending fatigue testing machine) shown in Fig. 2. The application stress is calculated from the applied moment according to the simple theory of a cantilever beam as: 


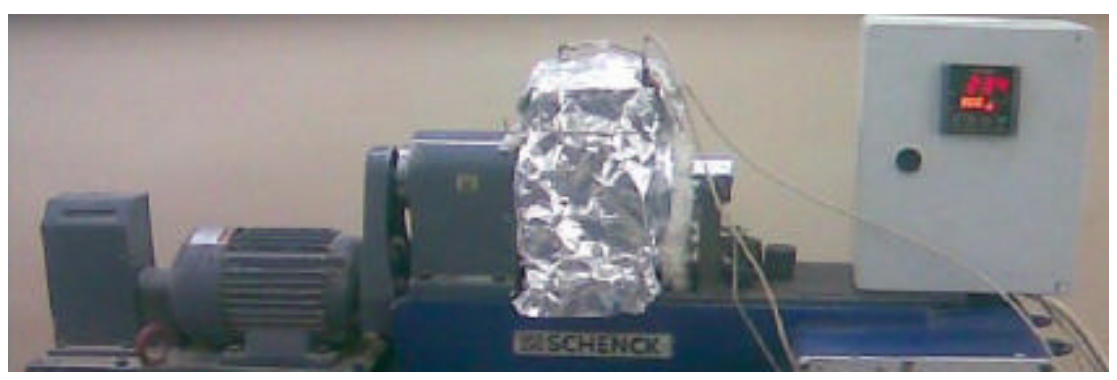

Fig. 3: Furnace attached to fatigue machine with control board

$$
\sigma=(1281 \mathrm{P}) / \mathrm{d}^{3}
$$

Where:

$\sigma=$ The bending stress in $(\mathrm{Mpa})$

$\mathrm{P}=$ The force in $(\mathrm{N}$.

$\mathrm{d}=$ The minimum diameter of the specimen $(\mathrm{mm})$

Constant fatigue tests are performed in laboratory with rotary fatigue bending rig at a stress ratio of $R=-1$. The failure is defined as the fatigue specimen becomes into two pieces. When specimen fails the fatigue testing automatically stops. The number of cycles until failure of the specimens are recorded by a mechanical counter which is coupled directly to the drive shaft of the d.c motor which records the number of stress cycles. This test is performed in the University of Technology/ Department of Electromechanical Engineering in Baghdad.

Thermal device: Fatigue at elevated temperature requires a thermal device for heating the environment of the specimens to a known elevated temperature. An electric furnace is manufactured with suitable dimensions of $(100 \times 120 \times 140 \mathrm{~mm})$. The furnace can be attached to the testing machine with a digital thermal control unit board. The walls of the furnace are made of two layers of steel plate with $3 \mathrm{~mm}$ thickness for each layer. An electrical heater of $(2000 \mathrm{~W})$ is fastened inside the furnace with a K-type thermocouple for the sake of controlling heating temperature inside the furnace. The furnace and digital thermal control unit board are illustrated in Fig. 3 .

\section{RESULTS AND DISCUSSION}

Constant amplitude fatigue results: The specimens were tested under constant amplitude fatigue stress rotating bending with a stress ratio $\mathrm{R}=-1$ at room temperature and for high temperatures $200^{\circ} \mathrm{C}$ to estimate the S-N curves. The results of aluminum alloy 7100 are given in Table (3-6) and plotted in Fig. 4.
Table 3: S-N curve results of Al7100 without heating Al. 7100 best zero

\begin{tabular}{|c|c|c|c|}
\hline $\begin{array}{l}\text { Applied stress } \\
\left(\sigma_{f}\right) \mathrm{MP}_{a}\end{array}$ & $\begin{array}{l}\text { No. of average cy cle to } \\
\text { Failure, } \mathrm{Nf}_{\mathrm{av}}\end{array}$ & Basquin equation & $\mathrm{R}^{2}$ \\
\hline 100 & 3600 & $\sigma_{\mathrm{f}}=236\left(\mathrm{~N}_{\mathrm{f}}\right)^{-0.10}$ & 0.997 \\
\hline 90 & 11000 & & \\
\hline 80 & 35000 & & \\
\hline 70 & 110000 & & \\
\hline
\end{tabular}

Table 4: S-N curve results of $\mathrm{A} 17100 \mathrm{wt} .6 \%$ nanocomposite without heating Al. 7100 best nano $6 \%$ alpha $\mathrm{Al}_{2} \mathrm{O}_{3}$

\begin{tabular}{lclc}
$\begin{array}{l}\text { Applied stress } \\
\left(\sigma_{\mathrm{f}}\right) \mathrm{MP}_{\mathrm{a}}\end{array}$ & $\begin{array}{c}\text { No. of average cycle to } \\
\text { failure, } \mathrm{Nf}_{\mathrm{av}}\end{array}$ & Basquin equation & $\mathrm{R}^{2}$ \\
\hline 100 & 4460 & $\sigma_{\mathrm{f}}=221\left(\mathrm{~N}_{\mathrm{f}}\right)^{-0.09}$ & 0.981 \\
90 & 22000 & & \\
80 & 67800 & & \\
70 & 215000 & & \\
\hline
\end{tabular}

Table 5: S-N curve results of A17100 at $200^{\circ} \mathrm{C}$

Al. 7100 zero nano

\begin{tabular}{lclc}
$\begin{array}{l}\text { Applied stress } \\
\left(\sigma_{\mathrm{f}}\right) \mathrm{MP}_{\mathrm{a}}\end{array}$ & $\begin{array}{c}\text { No. of average cycle to } \\
\text { failure, } \mathrm{Nf}_{\mathrm{av}}\end{array}$ & Basquin equation & $\mathrm{R}^{2}$ \\
\hline 100 & 1200 & $\sigma_{\mathrm{f}}=201\left(\mathrm{~N}_{\mathrm{f}}\right)^{-0.09}$ & 0.926 \\
90 & 8000 & & \\
80 & 21000 & & \\
70 & 44000 & & \\
\hline
\end{tabular}

Table 6: S-N curve results of A17100 wt. $6 \%$ nanocomposite at $200^{\circ} \mathrm{C}$ Al7100 best nano $6 \% \mathrm{Alpha}^{\mathrm{Al}_{2} \mathrm{O}_{3}}$

\begin{tabular}{|c|c|c|c|}
\hline $\begin{array}{l}\text { Applied stress } \\
\left(\sigma_{f}\right) \mathrm{MP}_{\mathrm{a}}\end{array}$ & $\begin{array}{l}\text { No. of average cycle to } \\
\text { failure, } \mathrm{Nf}_{\mathrm{av}}\end{array}$ & Basquin equation & $\mathrm{R}^{2}$ \\
\hline 100 & 3000 & $\sigma_{\mathrm{f}}=217\left(\mathrm{~N}_{\mathrm{f}}\right)^{-0.09}$ & 0.966 \\
\hline 90 & 16000 & & \\
\hline 80 & 48000 & & \\
\hline 70 & 125600 & & \\
\hline
\end{tabular}

S-N curves behavior: From the Basquin equations obtained from the experimental results and calculated according to $\sigma_{\mathrm{f}}=\alpha\left(\mathrm{N}_{\mathrm{f}}\right)^{b}$ where $\mathrm{a}$ and $\mathrm{b}$ are material constants. It is clear that, the above equations have good $\left(\mathrm{R}^{2}\right)$ correlation coefficient which proved that the experimental recorded data can be explained well using Basquin equation. Table 7 gives how the fatigue strength improved at $10^{3}$ and $10^{5}$ cycles due to addition the nanomaterial reinforcement. Relating to Table 7 , the difference in the FSIF are apparent. The above 


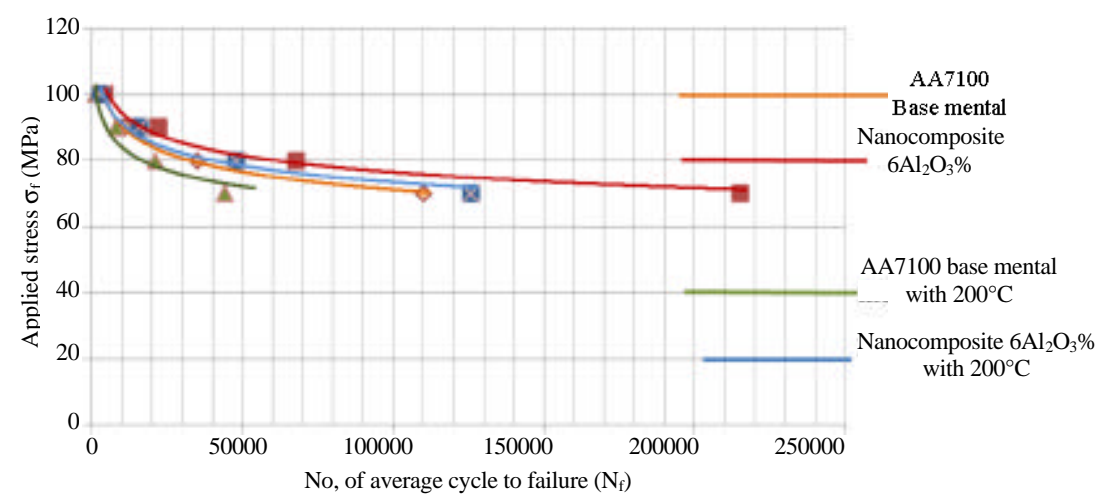

Fig. 4: S-N curves behaviors for four cases of testing

Tabe 7: S-N fatigue behaviours under $10^{3}$ and $10^{5}$ cycles

\begin{tabular}{|c|c|c|c|c|c|c|c|}
\hline \multicolumn{4}{|c|}{ Dry fatigue without and with 6 wt. $\% \mathrm{Al}_{2} \mathrm{O}_{3}$} & \multicolumn{4}{|c|}{ Thermal fatigue at $200 \mathrm{C}$ without and with $6 \mathrm{wt} . \% \mathrm{Al}_{2} \mathrm{O}_{3}$} \\
\hline \multicolumn{2}{|l|}{$10^{3}$ cycles } & \multicolumn{2}{|l|}{$10^{5}$ cycles } & \multicolumn{2}{|l|}{$10^{3}$ cycles } & \multicolumn{2}{|l|}{$10^{5}$ cycles } \\
\hline $\begin{array}{l}\text { Without nano } \\
(\mathrm{MPa})\end{array}$ & $\begin{array}{l}\text { With nano } \\
(\mathrm{MPa})\end{array}$ & $\begin{array}{l}\text { Without nano } \\
(\mathrm{MPa})\end{array}$ & $\begin{array}{c}\text { With nano } \\
(\mathrm{MPa})\end{array}$ & $\begin{array}{l}\text { Fatigue strength } \\
\text { with nano (MPa) }\end{array}$ & $\begin{array}{l}\text { Fatigue strength } \\
\text { with nano (MPa) }\end{array}$ & $\begin{array}{l}\text { Fatigue strength } \\
\text { with nano (MPa) }\end{array}$ & $\begin{array}{l}\text { Fatiguestrength } \\
\text { with nano(MPa) }\end{array}$ \\
\hline 118 & 119 & 74.6 & 78.4 & 108 & 116.5 & 71.3 & 77 \\
\hline \multicolumn{8}{|c|}{ Fatigue Strength Improvement Factor FSIF $=\frac{\sigma_{\text {nano }}-\sigma_{\text {unrœinforcœd }}}{\sigma_{10}} 100 \%$ (Asmaa et al., 2014) } \\
\hline 0.84 & & 4.84 & & 7.29 & & 7.4 & \\
\hline
\end{tabular}

Table 8: Mechanical properties of nanoreinforced material of $\mathrm{Al}_{2} \mathrm{O}_{3}$

\begin{tabular}{llcc}
\hline Hardness HB500 & $\begin{array}{c}\text { Tensile strength } \\
(\mathrm{MPa})\end{array}$ & $\begin{array}{c}\text { Elastic module } \mathrm{E} \\
\text { (GPa) }\end{array}$ & Ref. \\
\hline 1175 & 2100 Compression & 300 & (Mazahery et al. 2009)
\end{tabular}

Table 9: Endurance fatigue limit of base metal and composites at room temperature and at $200^{\circ} \mathrm{C}$

Room temp. $25^{\circ} \mathrm{C} \quad$ Room temp. $25^{\circ} \mathrm{C} \quad 200^{\circ} \mathrm{C}$ without $200^{\circ} \mathrm{C}$ withnano without nano with nanomaterial nano material

\begin{tabular}{llll}
\hline $47 \mathrm{MPa}$ & $51.8 \mathrm{MPa}$ & $46 \mathrm{MPa}$ & $50.86 \mathrm{MPa}$ \\
\hline
\end{tabular}

improvement is due to the hard nanoreinforced material of $\mathrm{Al}_{2} \mathrm{O}_{3}$ which has high hardness and mechanical properties as given in Table 8 according to (Mazahery et al., 2009).

According to, Table 7 when the fatigue life increased from $10^{3}-10^{5}$ the FSIF raised from $0.84-4.84 \%$ i.e. Increasing the fatigue life leads to increase the FSIF. For this reason the low cycle fatigue has little effect on the FSIF. In the thermal fatigue case, the FSIF improved from 7.29-7.4\%. Reducing the applied fatigue stress resulting in increase of FSIF for both dry and thermal fatigue.

Endurance fatigue limit at $10^{7}$ cycles: The 6 wt. $\%$ of $\mathrm{Al}_{2} \mathrm{O}_{3}$ nanoreinforced material has improved the fatigue property is most pronounced under conditions of high cycle fatigue (Low applied stress) but has little effect at low-cycle fatigue region (High applied stress). The reason for this case is that probably because the grain size generated with 6 wt. $\% \mathrm{Al}_{2} \mathrm{O}_{3}$ reduced to small grain size and this will retard fatigue cracks resulted long life. Table 9 gives the endurance fatigue limit at $10^{7}$ cycles.
Elevated temperature has a deleterious effect on the mechanical and fatigue properties of composite. Which can result in additional degradation of endurance fatigue resulted a degradation in fatigue life (Mars and Fatemi, 2004). According to the obtained experimental results given in Table 9, many workers reported that the fatigue life decreases with increasing testing temperature (Al-Alkawi et al., 2015). It is clear that, Table 9 gives best endurance fatigue limit of $51.8 \mathrm{MPa}$ for the composite tested at room temperature while the worst endurance fatigue limit is $46 \mathrm{MPa}$ for the base metal tested at $200^{\circ} \mathrm{C}$. The addition of nano reinforcement raised the value for fatigue strength at $10^{7}$ cycle from $47-51.8 \mathrm{MPa}$ and from 46-50.86 MPa for room and elevated temperature $200^{\circ} \mathrm{C}$. The high hardness and mechanical properties of alumina could be the main reason for enhancing the fatigue strength and endurance fatigue of the composite (Bharath et al., 2014).

\section{CONCLUSION}

The constant S-N curves fatigue strength and life of 7100 Al.alloy reinforced by 6 wt. $\%$ of $\alpha-\mathrm{Al}_{2} \mathrm{O}_{3}$ under rotating bending loading are investigated. The following conclusions may be derived from this research. The effect of 6 wt. $\% \mathrm{Al}_{2} \mathrm{O}_{3}$ on the fatigue strength improvement factor FSIF was obtained to be 0.84 and 4.84 for $10^{3}$ and $10^{5}$ cycles, respectively, at Room Temperature (RT). Increasing the fatigue life from $10^{3}$ and $10^{5}$ cycles resulted in an increase of 4 in FSIF. While the effect of nano reinforced material $6 \mathrm{wt} \% \mathrm{Al}_{2} \mathrm{O}_{3}$ on the FSIF at $200^{\circ} \mathrm{C}$ 
was recorded to be 0.11 . FSIF reduced from 4 at (RT) to 0.11 at $200^{\circ} \mathrm{C}$ due to the heating condition. The endurance fatigue limit at $10^{7}$ cycles of nano composite increased from 47-51.8 MPa at (RT) showing an improvement of $10.2 \%$. While this value increased from $46-50.86 \mathrm{MPa}$ at $200^{\circ} \mathrm{C}$ giving $10.56 \%$ improvement.

\section{REFERENCES}

Al-Alkawi, H.J., F.A. Kareem and A.A.M. Ali, 2015. Prediction of fatigue-creep interaction life of Aluminum Alloy AA7349 using electromechanical devices. Eng. Technol. J., 33: 535-547.

Asmaa, A.M., H.J. Al-Alkawi and F.A.F. Al-Bayati, 2014. Prediction of fatigue-creep interaction life of Aluminum and Copper Alloys using electromechanical devices. Msc Thesis, University of Technology, USA.

Aybarc, U., D. Dispinar and M.O. Seydibeyoglu, 2018. Aluminum metal matrix composites with $\mathrm{SiC}, \mathrm{Al}_{2} \mathrm{O}_{3}$ and grapheme-review. Arch. Foundry Eng., 18: 5-10.

Bharath, V., M. Nagaral, V. Auradi and S.A. Kori, 2014. Preparation of $6061 \mathrm{Al}-\mathrm{Al}_{2} \mathrm{O}_{3} \mathrm{MMCs}$ by stir casting and evaluation of mechanical and wear properties. Procedia Mater. Sci., 6: 1658-1667.
Majeed, M.H., D.S. Al-Fattal and H.J. Al-alkawi, 2010. Effect of hold time periods at high temperature on fatigue life in Aluminum Alloy 2024 T4. Eng. Technol. J., 28: 2608-2621.

Mars, W.V. and A. Fatemi, 2004. Factors that affect the fatigue life of rubber: A literature survey. Rubber Chem. Technol., 77: 391-412.

Mazahery, A., H. Abdizadeh and H.R. Baharvandi, 2009. Development of high-performance $\mathrm{A} 356 /$ nano- $\mathrm{Al}_{2} \mathrm{O}_{3}$ composites. Mater. Sci. Eng. A., 518: 61-64.

Mege-Revil, A., P. Steyer, S. Cardinal, G. Thollet and C. Esnouf et al., 2010. Correlation between thermal fatigue and thermomechanical properties during the oxidation of multilayered TiSiN nanocomposite coatings synthesized by a hybrid physical/chemical vapour deposition process. Thin Solid Films, 518: 5932-5937.

Stocker, C., M. Zimmermann, H.J. Christ, Z.L. Zhan and C. Cornet et al., 2009. Microstructural characterisation and constitutive behaviour of alloy RR1000 under fatigue and creep-fatigue loading conditions. Mater. Sci. Eng. A., 518: 27-34.

Zhang, X.P., C.S.H. Lim, Y.W. Mai and Y.W. Shi, 2006. Thermal Fatigue and Creep Fracture Behaviors of a Nanocomposite Solder in Microelectronic/ optoelectronic Packaging. In: Key Engineering Materials, Hu, H. and G. Xu (Eds.). Trans Tech Publications, Switzerland, pp: 237-242. 